\title{
Children's Rights in Secure Residential Youth Care in the Netherlands
}

\author{
S. J. C. Höfte \\ LLM, Youth Expert Centre, University of Applied Sciences, Leiden, \\ The Netherlands \\ hofte.s@hsleiden.nl \\ C. H.Z. Kuiper \\ $P h D$, Department of Child Development and Education, \\ University of Amsterdam, Amsterdam, The Netherlands \\ Horizon Youth Care and Education, Rotterdam, The Netherlands \\ chris.kuiper@horizon.eu

\section{G. H. P. van der Helm} \\ $P h D$, Youth Expert Centre, University of Applied Sciences, Leiden, \\ The Netherlands \\ helm.vd.p@hsleiden.nl
}

\section{S. M. de Valk}

$P h D$, IHUB, Amsterdam, The Netherlands sophie.devalk@altra.nl

\author{
G.J.J.M. Stams \\ $P h D$, Department of Forensic Child and Youth Care Sciences, \\ University of Amsterdam, Amsterdam, The Netherlands \\ g.j.j.m.stams@uva.nl
}

\begin{abstract}
This study examines the extent to which secure residential youth care in the Netherlands complies with children's rights as laid down in the United Nations Convention on the Rights of the Child (UNCRC) and the Dutch Youth Act. Residential group climate was measured with the Prison Group Climate Instrument (PGCI), which assesses quality of group care from the perspective of the three basic needs for human self-determination:
\end{abstract}


contact, autonomy and competence. Results indicate that children's rights are a subsidiary issue in secure residential youth care in The Netherlands, because groups workers and staff have insufficient understanding of children's rights and Dutch legislation on youth care. Dutch law allows secure facilities to make their own policy on youth care delivery, but it seems that policies are insufficiently explicit about children's rights. Results of this study can be used to work on the fulfilment of children's rights in secure residential youth care.

\section{Keywords}

children's rights - secure residential youth care

\section{Introduction}

More than 40,00o children in the Netherlands are unable to live with their parents due to an unstable or unsafe home situation (CBS, 2021). There are three forms of residential youth care in the Netherlands that differ in deprivation of liberty: open and secure residential youth care (the private setting) and juvenile justice institution (the penal setting).

Secure treatment in Dutch residential youth care facilities must comply with standards of international law and Dutch law. In this context, the Convention for the Protection of Human Rights and Fundamental Freedom (ECHR, 1950) and the United Nations Convention on the Rights of the Child (UNCRC, 1989) are the most important human rights conventions. Also, the United Nations Rules for the Protection of Juveniles Deprived of their Liberty (Havana rules, 1990) aim at the protection of human rights of the child in justice institution or other residential facilities.

As indicated in the preamble of the UNCRC, the child, by reason of his age and development, is entitled to a special approach, special protection and special rights. This special formulation of the child's human rights embodies the crucial added value of the UNCRC (Olujic and Forder, 2012). Almost all sovereign States in the world have ratified the Convention, except the United States of America, which has only signed it. As such, the UNCRC is the most widely accepted human rights instrument in the world. There is a universal understanding that children should be able to claim their human rights (Mijnarends, 2011). The United Nations has proclaimed that the child is entitled to special care and assistance: 'the child, by reason of his physical and mental immaturity, needs special safeguards and care, including appropriate legal protection, 
before as well as after birth'. The Dutch government has an obligation to respect children's rights, and the child's best interests should be a primary objective according to Article 3 of the UNCRC.

The UNCRC forms the framework for the justification of deprivation of liberty by admission into and retention within a secure residential facility. It provides the highest level of international standards and guidelines for regional and national implementation. Doek (2008) states that the UNCRC has enough leads and provisions that are important for answering the question if a (Dutch) law is in accordance with both the letter and the interpretation of the UNCRC.

When a State ratifies a convention, it takes on obligations under international law to implement it (Article 43 UNCRC). In other cases, it is possible that articles by their specific formulation and content are directly applicable to civilians. Under Dutch law, the national court is the only body which is competent to determine whether articles of the UNCRC have direct effect in the Dutch rule of law (Van Emmerik, 2005). This considers criteria such as nature, content, purpose and formulation of an article. Furthermore, direct effects of comparable articles from other human rights conventions can implicate direct effect in the Dutch rule of law (Ruitenberg, 2003). According to Dutch case law, Articles 2-12, 16, 19-23, 26-28, 37 and 40 of the UNCRC have increasingly been applied in the Dutch rule of law. Articles 3, 7, 9, 10 and 37 of the UNCRC are the most applied articles.

In recent years, the ECHR has developed into a convention which has been generally recognised as having far-reaching consequences for the Dutch rule of law. The ECHR and the jurisprudence of the European Court of Human Rights have often been quoted by Dutch judges at all levels (Barkhuysen, 2004). Therefore, all articles of the ECHR have a direct effect in the Dutch rule of law. The Havana rules are minimum standards geared to the juvenile justice system and the deprivation of liberty of children, but are not legally binding in the Dutch rule of law (Liefaard, 2008).

Article 5 paragraph 1 of the ECHR and Article 37 of the UNCRC impose very strict requirements, which must be satisfied if secure residential youth care is to be justified. Article 37 of the UNCRC provides that no child shall be deprived of his or her liberty unlawfully or arbitrarily, and detention shall be used only as a measure of last resort and for the shortest appropriate period of time; imprisonment must be strictly necessary and be as short as possible. Articles 2 and $11 b$ of the Havana rules make clear that the deprivation of liberty means any form of detention or imprisonment or the placement of a person in a public or private custodial setting, from which this person is not permitted to leave at will, by order of any justice, administrative or 
other public authority. Juvenile judges should act in the child's best interest in accordance with Article 3 of the CRC.

Deprivation of liberty by admission into and retention within a secure residential facility is allowed, but only for the purpose of educational supervision, according to Article 5 paragraph 1 under d of the ECHR. Unfortunately, the ECHR does not give a specific definition about the meaning of educational supervision. In Koniarksa $v$ United Kingdom (200o appl. no. 33670/96), the European council did explain what it is not:

The words 'educational supervision' must not be equated rigidly with notions of classroom teaching ... Such supervision must embrace many aspects of the exercise, by the authority, of parental rights for the benefit and protection of the person concerned.

And in Blokhin v Russia (2016, appl. no. 47152/o6 para. 170):

'Educational supervision' must nevertheless contain an important core schooling aspect so that schooling in line with the normal school curriculum should be standard practice for all detained minors, even when they are placed in a temporary detention centre for a limited period of time, in order to avoid gaps in their education.

The case of Bouamarv Belgium (1988 appl. no. 9106/80, para. 52) stated that the State's obligation is to put in place appropriate institutional facilities that meet the security and educational demands of that system:

The detention of a young man in a remand prison in conditions of virtual isolation and without the assistance of staff with educational training cannot be regarded as furthering any educational aim.

According to Article 6.1.2 Youth Act, a juvenile court can place a child in a secure residential youth care facility when the child shows serious psychiatric or behavioural problems. Such an authorisation can only be given when a child seriously jeopardises his or her own development and becomes a danger to him- or herself or society when less invasive forms of treatment have not been sufficient. According to Article 2.3 paragraph 6 of the Youth Act, a judge should be convinced that ambulatory or open residential treatment is inadequate to provide the protection needed by the child when the judge grants power to the Youth Care Authority to permit admission of a child to a secure care residential facility. This is not an easy decision, because the judge should balance treatment 
needs with a judicial major decision to take away freedom from a growing child with possible negative consequences, which are also connected to secure treatment (De Valk et al., 2016). In 2020, the juvenile court placed 1,366 children in a secure residential youth care facility (Jeugdzorg Nederland, 2020).

Whether children's rights are safeguarded depends to a great extent on the quality of care provided within the facility. Compliance with children's rights is only achieved if the facility in question provides a safe and therapeutic climate (Van der Helm et al., 2011a). Imposition of restrictive measures and application of control measures must, according to Article 4.1.1 of the Youth Act, comply with the principle of responsible care. This will be defined as: 'A high care level, in any case safe, effective, efficient and client focused and adapted to the real needs of the client or parent.'

Before 2010 all children in secure or justice custodial settings were placed together in one and the same institution (Boendermaker \& Bruinsma, 2007). In 2008, the legislature decided that these two groups of children should be placed in different institutions, which led to the foundation of secure residential facilities (Kamerstukken [Parliamentary papers] II, 2012). Many of the existing secure care facilities were originally juvenile justice institutions, and many of the staff working in these institutions were trained in the field of penal detention. Secure residential facilities have in practice a broad discretion regarding the application of restrictions of freedom (Van der Helm et al., 2011a). Because of this, all depends on the professional behaviour of the staff providing secure care. Notably, lack of professional behaviour may harm children (Heynen et al., 2017; Van der Helm et al., 2011a).

We consider "therapeutic residential care" as defined by Whittaker et al. (2014: 24) as a basic standard for how care ought to be delivered:

'Therapeutic residential care' involves the planful use of a purposefully constructed, multi-dimensional living environment designed to enhance or provide treatment, education, socialization, support, and protection to children and youth with identified mental health or behavioural needs in partnership with their families and in collaboration with a full spectrum of community-based formal and informal helping resources.

This definition is widely accepted, by among others the International Work Group on Therapeutic Residential Care and endorsed by different worldwide associations (the European Scientific Association on Residential and Family Care for Children and Adolescents (EUSARF); the International Association for Outcome-Based Evaluation and Research on Family and Children's Services (IAOBER); the Association of Children's Residential Centers (ACRC) (USA); 
and the Centre of Excellence for Looked After Children in Scotland (CELCIS). Although not described explicitly, we consider the underpinning values, e.g. first, do no harm, strive constantly to forge and maintain strong and vital family linkages, strategies for practice are sufficiently clear in procedures, structures and protocols to provide for full access to service in a given locality, region or jurisdiction (Whittaker et al., 2016), congruent with the CRC standards.

Living in secure residential youth care usually takes place in care units or living groups, with approximately eight to ten children together in one unit, supervised by trained social workers. Group climate has been defined by Stams and Van der Helm (2017) as:

The quality of the social and physical environment in terms of the provision of sufficient and necessary conditions for physical and mental health, well-being, contact and personal growth of the residents, with respect for their human dignity and human rights as well as (if not restricted by judicial measures) their personal autonomy, aimed at recovery and successful participation in society.

Children in secure residential care often present a danger to themselves (e.g., substance use, psychiatric problems, behavioural problems, refusing education) or others (e.g., aggression, criminal behaviour) (Anckarsäter et al., 2007; Colins et al., 2010; Fazel et al., 2008; Leloux-Opmeer et al., 2016). They often refuse any form of compulsory treatment and may react aggressively (Van der Helm et al., 2011a). This aggression can provoke non-professional behaviour by social workers (Van der Helm \& Stams, 2012). For example, staff may use coercive measures as behavioural punishment (De Valk et al., 2015) or consciously or unconsciously misuse the power they inevitably exceed (Souverein et al., 2013). This harmful behaviour may be referred to as repression.

In the scoping review by De Valk et al. (2016), repression was defined as an authority figure intentionally acting in a way that harms the youth, or by an authority figure unlawfully or arbitrarily depriving the youth of liberty or autonomy. De Valk et al. (2016) state that repression is hidden in aspects that are an essential part of residential youth care, such as (soft) power, structure, and coercion. These aspects become repressive when used harmfully, unlawfully or arbitrarily. Arbitrary use of power, structure and coercion may result in youth viewing staff's behaviour as unpredictable, unfair and unsafe, which may cause reaction and: demotivation in youth, hindering effective treatment in residential youth care.

As De Valk et al. (2016) specifically state, it is crucial to monitor compliance with children's rights within secure residential youth care. Because group 
climate influences whether, when and how the rehabilitative and educational goals of residential care can be achieved (Heynen et al., 2017; Souverein et al., 2013; Stams and Van der Helm, 2017), it is important regularly to assess residential group climate. Moreover, the effectiveness of youth care can be enhanced by acknowledging gender-specific and age differences (Sonderman et al., 2015).

Residential group climate can be measured with the Prison Group Climate Instrument (PGCI; Van der Helm et al., 2011b), which assesses quality of group care from the perspective of the three basic needs for human self-determination (Van der Helm et al., 2018): contact (i.e., having meaningful and supportive social relationships), autonomy (i.e., making free choices), and competence (i.e., opportunities for personal growth). The PGCI distinguishes between four elements: Support, Growth, Repression and Atmosphere. These elements can be related to children's rights laid down in the UNCRC. The scale Support refers to the professional quality of the behaviour of social workers and the responsiveness of the social worker towards the child's special needs. According to Article 3 of the UNCRC, all actions concerning the child shall take full account of his or her best interests. The scale Growth indicates the extent to which a child feels that he is learning something, has hope for the future and understands the purpose of his or her stay in the secure residential youth care facility. According to Article 6 of the UNCRC, governments should ensure that children survive and develop healthily. Repression corresponds with Article 13 of the UNCRC, stating that children have the right to express their own views and to be taken seriously and be treated fairly. Furthermore, according to Article 12 of the UNCRC, children have the right to be heard in all matters that affect them. Article 37 of the UNCRC and Article 5 paragraph 1 under $d$ of the EHRC state that deprivation of liberty is only allowed for the purpose of educational supervision. Atmosphere refers to the child's experience in the way the children respect and trust each other at the living group and feel safe (Van der Helm et al., 2011a).

Facilities delivering secure residential youth care are regularly subject to governmental inspections. In the Netherlands, these inspections are carried out by the Inspection of Youth Care and the Joint Inspections, which is a collaboration of several inspections within the social domain.

This study is unique because there has been no previous research in the Netherlands into whether the care delivered in secure residential youth care, as experienced by children, meets the requirements as described in the Articles 
of the UNCRC and the Youth Act. Other studies of secure residential youth care deal with the living group climate in secure residential youth care and juvenile justice institutions and about safety and repression in these facilities (e.g. Van der Helm et al., 2011a; Van der Helm et al., 2018, De Valk, 2019a). In this study the UNCRC and the Youth Act will be taken as a guideline. It is expected that youth in residential facilities experience a more positive living group climate than youth in juvenile justice institutions, because the review by De Valk et al. (2016) showed that the justice settings may be characterised by more repression due to the correctional goal. On the contrary, secure residential facilities are originally more focused on treatment and rehabilitation. A quantitative analysis is first conducted to investigate whether youth in different types of institutions experience differences in living group climate. Subsequently, a qualitative analysis is conducted using frame analysis to investigate whether the care provided in the different types of institutions meets the requirements as described in the Articles of the UNCRC and the Youth Act.

\section{$3 \quad$ Method}

\subsection{Quantitative Research}

The present cross-sectional study examines differences in living group climate between open and secure residential facilities and juvenile justice institutions.

\subsubsection{Participants}

The total sample consisted of $N=838$ children. The first subgroup contained 310 children, aged 10 to 19 years, who received open residential youth care; 169 boys ( 54.5 per cent) and 132 girls ( 42.6 per cent) with an average of 15.44 years. The second subgroup contained 387 children aged 120 to 18 years receiving secure residential youth care; 214 boys ( 44.7 per cent) and 173 girls (44.6 per cent) with an average of 15.43 years. The third subgroup, children in juvenile justice institutions, consisted of 241 children aged 14 to 23 years; two 240 boys (99.2 per cent) and one girl (o.4 per cent) with an average of 18.37 years.

\subsubsection{Procedure}

A sample of 838 children in open and secure residential facilities, and the juvenile justice institutions, participated voluntarily. The children were approached to participate in the study by the social workers in their unit. The children were told that the data would be treated confidentially, analysed anonymously by the researchers and used for research purposes only. The data cannot be traced back to the names of the participants. The databases could not be accessed by 
the social workers or the youth care facilities. The children were asked to confirm this information by signing an informed consent form. The study protocol was approved by the ethical committee of the Leiden University of Applied Sciences.

\subsubsection{Research Instrument}

The PGCI consists of 36 items on a five-point Likert-type scale, ranging from 1 $=$ 'I do not degree' to $5=$ 'I totally agree'. Each item belongs to one of the four scales for group climate. The scale Support (12 items) assesses perceived professional behaviour and in particular the responsiveness of group workers to specific needs of the children. An example of a support item is: 'group workers treat me with respect'. The scale Growth (9 items) assesses learning perceptions, hope for the future and giving meaning to the stay in the institution. An example of a growth item is: 'I learn the right things here'. The scale Repression (7 items) assesses perceptions of strictness and control, unfair and haphazard rules and lack of flexibility at the living group. An example of a repression item is: 'You have to ask permission for everything here'. The scale Atmosphere (7 items) assesses the way children treat and trust each other, feelings of safety towards each other, being able to get some peace of mind and having enough daylight and fresh air. An example of an atmosphere item is: 'We trust each other here'. The score of a respondent is established by adding up the response to all the items falling within the scale and dividing this outcome by the number of items within the scale. A high score on Support, Growth and Atmosphere means a positive outcome. A high score on Repression gives a negative outcome. Cronbach's alpha reliability coefficients of the four scales were good: support $\alpha=.90$, growth $\alpha=.88$, repression $\alpha=.76$ and group atmosphere $\alpha=.76$. The PGCI was validated in 2011, showing favourable construct validity (confirmatory factor analysis) and reliability (Van der Helm, et al., 2011b).

\subsubsection{Data Analysis}

Preliminary analysis was conducted to check whether the prerequisite assumptions of MANOVA/MANCOVA were met (Bray and Maxwell, 1985). Thus, the assumptions centred to MANOVA/MANCOVA in the statistical analysis were examined for: (a) multivariate normality, (b) equality of group population covariance matrices, (c) linear relationship between covariates and dependent variables, (d) absence of multicollinearity, and (e) homogeneity of dependent variable variance.

To examine if there were any significant statistical differences among the children's mean scores on Support, Growth, Repression and Atmosphere across the three groups (Table 1), a one-way multivariate analysis of covariance 
(MANCOVA) was conducted (with age and gender as the covariates). By employing the MANCOVA, the extraneous differences among groups can be controlled after removal of the effects of the covariates from the dependent variables (Hair et al., 2010). If the overall multivariate test (MANCOVA) was significant, a univariate F test (ANCOVA) was carried out with, again, age and gender as covariates, in order to examine further if there was a significant statistical main effect of type of residential care on experienced living group climate.

The assumptions for the MANCOVA and inferential statistics analyses were tested using SPSS (Version 23). As there were missing data, the sums of squares were changed to Type IV. Type IV sums of squares are computed by equitably distributing cell contrast coefficients for lower-order effects across the levels of higher-order containing interactions. With this customised model, there were 296 children in the open residential care group, 315 in the secure residential care group, and 227 in the juvenile justice care group. The effect size index (f) was calculated from eta square ( $\eta 2)$. According to Cohen's rough characterisation (Cohen, 1988: 284-288 and 1992), $0.2 \leq \mathrm{f} \leq 0.4$ is deemed as a small size effect, $0.4<\mathrm{f} \leq 0.7$, a medium size effect, and $0.7<\mathrm{f} \leq 1.0$, or $1 \leq \mathrm{f}$ as the large size effect (for interpreting $\eta^{2}, 0.010 \leq \eta^{2} \leq 0.039=$ small, $0.039<\eta^{2} \leq 0.11=$ medium, and $0.11<\eta 2 \leq 0.20=$ large effect size).

TABLE 1 Descriptive Statistics of the Dependent Variables (Means and Standard Deviations)

\begin{tabular}{llrrr}
\hline Dependent variables & Facility/Institution & $\boldsymbol{N}$ & $\boldsymbol{M}$ & $\boldsymbol{S D}$ \\
\hline Support & Open & 296 & 3.50 & 0.78 \\
& Secure & 315 & 3.24 & 0.93 \\
& Justice & 227 & 3.29 & 1.00 \\
Growth & Total & 838 & $3 \cdot 35$ & 0.90 \\
& Open & 296 & $3 \cdot 39$ & 0.93 \\
& Secure & 315 & 3.25 & 1.10 \\
Repression & Justice & 227 & 3.03 & 1.09 \\
& Total & 838 & 3.24 & 1.05 \\
& Open & 296 & 3.30 & 0.68 \\
& Secure & 315 & 3.48 & 0.69 \\
Atmosphere & Justice & 227 & 3.33 & 0.75 \\
& Total & 838 & 3.38 & 0.71 \\
& Open & 296 & 3.11 & 0.78 \\
& Secure & 315 & 2.90 & 0.86 \\
& Justice & 227 & 3.24 & 0.97 \\
& Total & 838 & 3.07 & 0.87 \\
\hline
\end{tabular}




\section{2}

\section{Qualitative Research}

\subsection{1}

Data Collection

The qualitative study is based on a secondary analysis of an existing database that consists of semi-structured interviews with youth in residential youth care $(n=384)$. The interviews were conducted as part of the research project, "What works in residential youth care?", financed by a NWO SIA-RAAK funding. For this project all participating residential facilities were asked to recruit youth to participate. Youth were selected by means of convenience sampling. These data were obtained through informal data sharing, as the primary researcher is also part of the secondary analysis team (Heaton, 2008). From 2009 to 2014, students of the University of Applied Sciences Leiden and the University of Amsterdam who registered for the interviews as part of their thesis or a research course conducted the interviews. Students received training (i.e., education about youth in residential youth care, preparing an interview, conversation skills, dealing with dilemma's during the interview) from researchers of the University of Applied Sciences Leiden. All students involved signed a non-disclosure agreement. When the students first met the youth, they explained that their data would be treated confidentially, anonymously and used for research purposes only. Those youth who wished to participate in the research were asked to sign an informed consent form. The interviews took about 45 minutes. The researchers used a topic list to guide the semistructured interviews considering the four elements of living group climate (Van der Helm et al., 2011b): support from staff, growth, repression and atmosphere. All interviews were conducted at the residential facilities in a separate room from the ward. As a token of gratitude for their participation, the youth received a small reward, which was agreed upon with the facility (for example, shower gel or a magazine). The interviews were audio recorded and the students were asked to transcribe the interviews verbatim for coding purposes.

\subsubsection{Data Selection}

This secondary analysis of the data is supplementary, because it provided a good indication what happens when a child is living at the secure care accommodation. To ensure that the original data can be used to meet the aims of the current study, several steps have been followed. First, only the interviews in the secure residential youth care were selected $(n=251)$. Then the interviews that were not transcribed verbatim and were remarkably short were excluded $(n=53)$. Finally the interviews before 2012 were excluded $(n=17)$. In 2008 the secure residential facilities were founded and until 2010 a transitional phase arose to place the right children in a secure facility. Because of this the number of secure placed children temporarily increased in the years 2008-2010, 
following by a decrease with a tendency to stabilise in 2012 (Dresen et al., 2017). We have limited this study to this stabilised period.

From the 12 participating organisations interviews were randomly selected one by one. If the transcript included relevant information, the depth and richness of these parts was judged (Moerman, 2010; Rubin and Rubin, 2012). This selection process continued until saturation was reached. More specifically, the sampling process was terminated once no new unlawful aspects had been uncovered. This sample consisted of 50 children in the age group of 12 to 18 years (22 boys ( 66 per cent) and 17 girls (34 per cent)), who all stayed in secure youth care accommodations. The average age was 15.47 years.

\subsubsection{Analysis}

The transcribed interviews were analysed through frame analysis (Goffman, 1974), which is an approach of deductive analysis: codes were pre-selected based on the articles of the UNCRC and open coding was used to ensure that important aspects of the data were not missed. Every topic in the interview covered an article of the UNCRC and were - inter alia - freedom of expression, health care, adequate standard of living, education, leisure and recreation. One researcher then applied this working analytical framework by indexing subsequent transcripts. The data from each transcript were subsequently charted by category. Throughout the study a research diary was kept to record impressions of the data and thoughts about interpretation. During the analysis, Atlas.TI software was used to support the organisation and categorisation of data.

\section{$4 \quad$ Results}

\subsection{Quantitative Results}

The assumption of homogeneity of variance-covariance matrices was interpreted as significant (Box's $M$ value $=84.766, p=.000$ ), assuming the covariance matrices between the groups was unequal. Furthermore, the Levene's test of equality of variances was significant for three dependent variables: Support, Growth and Atmosphere. However, as the sample sizes were equal (no more than 5 o per cent difference between smallest and largest group), the Box's test could be disregarded and Pillai's Trace statistics to evaluate the multivariate differences was assumed to be robust (Field, 2016).

After adjusting for age and gender, there was a significant difference between the three groups on the dependent variables (Pillai's Trace $=.045, \mathrm{~F}$ $(8,1662)=4.790, p<.001$, partial $\left.\eta^{2}=.023\right)$. Follow-up ANCOvA showed that there was a significant main effect of type of institution on all four dependent 
variables: $\operatorname{Support}\left(F(2,833)=7.34 ; p<.025 ;\right.$ partial $\left.\eta^{2}=.017\right)$, Growth $(F(2,833)$ $=3.40 ; p<.05 ;$ partial $\left.\eta^{2}=.008\right)$, Repression $\left(F(2,833)=5.19 ; p<.025 ;\right.$ partial $\eta^{2}=$ $.012)$, and Atmosphere $\left(F(2,833)=6.06 ; p<.025 ;\right.$ partial $\left.\eta^{2}=.014\right)$. A Bonferroni correction was made to account for multiple ANOVAs being run. None to small associations between type of institution and dependent variables were obtained, indicating that 1.7 per cent (Support), o.8 per cent (Growth), 1.2 per cent (Repression) and 2.5 per cent (Atmosphere) of the variance obtained was accounted for by the type of institutions.

Further testing using the Post hoc Pair-wise test (Table 2) revealed that youth in open residential youth care experienced significantly more support than youth in secure residential youth care $(p<.001)$, more growth than youth in juvenile justice institution $(p<.05)$, less repression than youth in secure residential youth care $(p<.05)$, and a better atmosphere than youth in secure residential youth care $(p<.05)$. Furthermore, youth in juvenile justice youth care experienced a better atmosphere than youth in secure residential youth care $(p<.05)$.

TABLE 2 Summary of post hoc pairwise comparison

Comparisongroup Cohen's Meandifference Sig.

Support

Open vs. Secure

.30

.23

.269

.229

$-.039$

Secure vs. Justice

$-.05$

Growth

Open vs. Secure

Open vs. Justice

Secure vs. Justice

.075

1.000

Repression

Open vs. Secure

$-.26$

Open vs. Justice

$-.04$

Secure vs. Justice

.21

$-.182$

$-.121$

.061

Atmosphere

Open vs. Secure

.26

.214

Open vs. Justice

$-.15$

Secure vs. Justice
$-.036$

$-.37$
$.004^{*}$

.397

1.000

$.006 *$

1.000

.311

.039 *

.532

$.030 \%$ 


\subsection{Qualitative Results}

In this section, we will describe if the children's experiences are in accordance with the Articles from the UNCRC or say anything about violation of children rights.

\section{Article 12 of the UNCRC: Freedom of Expression}

Article 12 UNCRC is a unique provision in a human rights treaty: it addresses the legal and social status of children who, on the one hand lack the full autonomy of adults but, on the other, are subjects of rights (UNCRC General Comment No. 12, 2009, para. 1). It requires a preparedness to challenge assumptions about children's capacities, and to encourage the development of environments in which children can build and demonstrate capacities. The child has the right to express his own views on all that matters to him or her, and this view must be accorded sufficient weight by those taking decisions, which affect him or her. General Comment No. 12 is very clear.

It is the right of every child without any discrimination. Achieving meaningful opportunities for the implementation of Article 12 will necessitate dismantling the legal, political, economic, social and cultural barriers that currently impede children's opportunity to be heard and their access to participation in all matters affecting them.

Dutch judges ruled in several cases that this Article has direct effect in the Dutch rule of law (Ruitenberg, 2004). Most of the children were negative about the way they can express their own view on things. One child indicated that no discussion is possible with staff members:

Well, look, when you do have a compliant, then they go ..., if they don't hear you or you may not complain or you can go to your room. You can't do anything. They can put you in isolation, but they do not listen. They are not taking anything seriously $\left(\mathrm{R}_{323}\right)$.

A couple of children reported staff members abusing their power by sending them to their rooms. One child illustrates:

Well, the staff has power, and they also make that very clear. ... For example, when you make a joke with someone and the staff did not recognise that's a joke and then you enter into a discussion. Despite the fact that they are wrong they will send you to your room. They can't handle it when a child is right. When a child enters into a discussion and they win, eventually the child must go up to his room. They abuse their power. 
Pressing the alarm far too quickly, these sort of things $\left(\mathrm{R}_{3} 6 \mathrm{o}\right)$.

One child explains why he never tells anything to a staff member:

And you cannot trust the staff members at all because they cannot keep information private. And then everyone in the organisation knows (R319).

Most of the children explain that they want to be seen and heard by staff. A couple of children explain that, when the staff member has time, he will listen. But they do not know whether they actually do anything with it.

\section{Article 24 of the UNCRC: Health Care}

The United Nations Committee states in General Comment No. 15 that the health of the child is:

... an inclusive right extending not only to timely and appropriate prevention, health promotion, curative, rehabilitative and palliative services, but also a right to grow and develop to their full potential and live in conditions that enable them to attain the highest standard of health by implementing programmes that address the underlying determinants of health.

UNCRC GENERAL COMMENT NO.15, 2013, PARA 2.

The child is entitled to the highest attainable standard of health care, with an emphasis on basic health and the development of preventive health care (Spronk, 2011). Article 24 had no direct effect on the Dutch rule of law (Kamerstukken [Parliamentary papers] II, 1992/93). But it can be used as a framework by the Dutch government to set their own priorities for health care. The States should provide these children with all the necessary services. The United Nations Committee stated further that:

The health and development of adolescents are strongly determined by the environments in which they live. Creating a safe and supportive environment entails addressing attitudes and actions of both the immediate environment of the adolescent.

UNCRC GENERAL COMMENT NO. 4 2003, PARA. 14

The United Nations Committee is also very concerned about the high rate of suicide among this age group:

Mental disorders and psychosocial illness are relatively common among adolescents. In many countries symptoms such as depression, eating dis- 
orders and self-destructive behaviours, sometimes leading to self-inflicted injuries and suicide, are increasing.

Under Article 24 of the Convention, States parties are urged to provide adequate treatment and rehabilitation for adolescents with mental disorders (UNCRC General Comment No. 4 2003, paras. 22 and 29).

In the interviews a distinction between two types of health care emerged: physical and psychological care.

Concerning the physical care, most of the children indicated that their physical complaints became worse after having stayed for some time in the facility. Most of the children indicated that they had sleeping problems. This child illustrates the problem very clearly:

... The stress of imprisonment. That I cannot go outside anytime I want to buy cigarettes (R391).

The next quote illustrates that it is important to take into account the characteristics of the child: I am someone who wants to have everything under control. And because I am here, I cannot have that much control of myself. So, what happens is that I want to control absolutely everything and that drives me crazy. Because when I don't have control, well, then it is game over for me $\left(\mathrm{R}_{329}\right)$.

Concerning the psychological care, a couple of children believed that they were receiving inadequate psychological aid, because - according to them - a wrong diagnosis had been made. One child explains:

Well, the things they say after a personal research. Attachment problems, PDD-nos, ODD, ADHD, I had them all. Oh well, everybody has them know (R389).

Some considered that their afflictions were ignored by the staff members or their depressive behaviour was punished.

\section{Articles 28 and 29 of the UNCRC: Education}

The child's right to education is not only a matter of access (Art. 28) but also of content (UNCRC General Comment No. 1, 2001, para. 3). The State should encourage the development of different forms of secondary education and make it available for each child. The right to education is a fundamental right. Education must focus on the development of the personality in the light of the talents and skills of the child. Any form of school discipline should take into 
account the child's human dignity and must be in accordance with the UNCRC. School administrators must review their discipline policies and eliminate any discipline practices involving physical or mental violence, abuse or neglect. The direct effect of these Articles has not being discussed by a Dutch judge, but the government has an obligation to realise these rights.

From the interviews it emerges that many more children were unhappy about education than satisfied. They reported that the level of education did not reflect their own standard and abilities. It is striking that before they entered the facility, most of the children followed an education at a higher level than during the period of secure care. Almost all children indicated that they did not learn enough. One child explains:

School is boring. It isn't really like school. I'm playing cards all day. That's it. We do have teachers, but they don't teach. They are just sitting there and give you something to do. They warn you a couple of times, and otherwise you must return to the living group. That's it. That's all you do here at school (R355).

The selection of types of education that can be followed is inadequate because in some facilities youth can only choose from a limited number of school subjects. Two children also reported that no education at all is given when the teacher is ill. One child also indicated that some teachers do not know how to deal with the children. The child illustrates:

To be honest, the supervisors at school, they could use a couple of courses because the last time a couple of complaints have been made about children been beaten by teachers. I will be quite honest, I saw how pupils being knocked down by teachers at school and running through the hall (R368).

A couple of children mentioned that that the level of education was consistent with their own level.

Article 31 of the UNCRC: Leisure, Play and Culture

The United Nations Committee states in general comment No. 17 that:

States shall take all appropriate measures to ensure that all children have the opportunity to realize their rights under article 31 without discrimination of any kind ... Particular attention should be given to addressing the rights of certain groups of children, including health-care or residential institutions. 
UNCRC GENERAL COMMENT NO. 17, 2013, PARA. 51

States should adopt measures to ensure that all such institutions guarantee both spaces and opportunities for children to associate with their peers in the community, to play and to participate in games, physical exercise, cultural and artistic life. Such measures should not be restricted to compulsory or organized activities; safe and stimulating environments are needed for children to engage in free play and recreation. Availability of time, appropriate space, adequate resources and equipment, trained and motivated staff and provision of dedicated budgets are needed to create the necessary environments to ensure that every child living in an institution can realiSe his or her rights under Article 31. This Article has no direct effect on the Dutch rule of law (Kamerstukken [Parliamentary papers] II, 1992/93).

The interviews revealed that some facilities do not comply with this obligation. Almost all children reported that they were bored at the group:

There is nothing to do here. We don't have a sports teacher. The law and the day routine say that we have the right to two sports moments a day but we never have them. We would really like to use up all our energy $\left(\mathrm{R}_{3} 6 \mathrm{o}\right)$.

They considered that not enough activities were organised. Almost half of the children reported that they were sent to their rooms without a justified reason and for too long a period of time. A couple of children reported that it is standard procedure in some facilities that a newcomer must stay in his or her room for the first three days without any special reason:

My first day's here? Sorry, I can't remember. Just boring, I was in my room, all the time. Almost the whole week actually $\left(\mathrm{R}_{355}\right)$.

\section{5 \\ Discussion}

The quantitative results from the questionnaires indicate that the correctional juvenile justice institutions had a more open and positive group climate for the child than secure residential facilities. The level of support, growth and atmosphere in the secure residential facility was not higher and the level of perceived repression lower than in a juvenile justice institution.

The qualitative study offers sufficient grounds to support the quantitative findings in that children perceived significantly more negativity in the secure 
residential facility. The interviews confirm a number of difficult issues regarding the care delivered in secure facilities. The United Nations Committee has stated frequently that the health and development of children are strongly determined by the environments in which they live. Some children state that the physical complaints became worse after being in the facility due to increased stress as a consequence of deprivation of liberty and an insufficient quality of group climate. The formal education did not always fit the educational level of the child, as limited possibilities for (lower) education were usually offered, and staff members sometimes abused their power, which resulted in repression.

Results of this study suggest that some secure facilities are not always able to provide a therapeutic group climate within the facility. This is remarkable because - unlike juvenile justice institutions, where children with convictions are detained - secure residential facilities have primarily a care objective, and the element of punishment (repression) should be expected to be less present than in a juvenile justice institution. The average stay in secure residential facilities is often longer, (6.5 months) (Jeugdzorg Nederland, 2020) than a stay in juvenile justice institutions (8o days) (DJI, 2019). As De Valk et al. (2016) observe, repression in residential facilities can manifest itself openly in coercive measures or may be concealed in staff behaviour that is endemic to residential youth care, such as soft power and strict behavioural control. The quality of care in the secure facility must provide the justification for freedom restriction. Without justification the restrictions in secure residential facilities are in violation of Art. 37 UNCRC and Art. 5 ECHR. As stated before, the law is not considered to be specific enough. It gives the facilities freedom to decide on their own policy. Lack of knowledge about professional behaviour can result in powerlessness and ignorance, and unfair treatment of children, who may get hurt.

Whittaker et al. (2016) view their definition of "therapeutic residential care" as a step in the direction of establishing a common language for therapeutic residential care, as it provides a place at the table for policy discussion. His workgroup developed a research agenda for therapeutic residential care with clear potential for cross-national collaboration. Based on our observations in this study, we like to add children's rights as an important research lens to their specific Promising Pathways for Future Research in Therapeutic Residential Care.

\subsection{Limitations}

The PGCI is not a norm-referenced, standardised instrument. It was therefore not possible to establish whether overall repression was generally low or high in the residential institutions compared to residential or non-residential group care in general. However, interviews confirmed that some children 
were negative about the care delivered in the residential facilities, and examples of repression were given in the interviews. This study was based on selfreporting of children. It cannot be ruled out that their perception was positively or negatively biased, for instance, giving socially desirable answers (i.e., faking good), showing cognitive bias (e.g., hostile attribution), or giving a bad image of themselves (i.e., faking bad). However, the purpose of this study was to let the children speak for themselves and assess their subjective experiences. Notably, this study does not provide an objective image of the group climate in the residential facilities, but shows how children did experience their stay in residential care.

\section{6}

\section{Conclusion}

To our knowledge, this is the first study in the Netherlands examining whether care delivered in secure residential facilities, as experienced by children, meets the requirements as described in the Articles of the UNCRC and the Dutch Youth Act. From the children's perspective, there are some indications that secure residential facilities do not always apply sufficient safeguards to the fundamental rights of the child. This is in line with the United Nations Study on Children deprived of their liberty, which stated that in most States, conditions of detention, in all contexts, are deplorable and do not meet international standards (United Nations, 2019) and it is also in line with the results from the qualitative study that was carried out by De Valk et al. (2019).

We acknowledge the United Nations position that deprivation of liberty means deprivation of rights, agency, visibility, opportunities and love. Depriving children of liberty is depriving them of their childhood (United Nations, 2019:4). The main goal of freedom restriction is to protect and treat the child, which means that restriction of freedom must be in full compliance with the law in order to be justified. It is therefore remarkable that the group climate in secure residential facilities differed only slightly from the group climate in juvenile justice institutions (for a similar result, see Van den Tillaart, 2018). It is questionable whether the restriction of freedom is justified under these conditions. A better climate, together with a good learning climate at school, can ensure that facilities will meet the requirements of (inter)national conventions. Reduction of repression is the most important issue that the facilities should address, which calls for de-escalation tactics instead of force (Van Gink, 2019). Secure residential youth care has a responsibility to act on this.

Our research findings are corroborated by the research report on violence in youth care in the Netherlands from 1945 until 2018, which had been 
commissioned by the Dutch government (Committee Violence Youth Care, 2019). Conclusions were that violence was present throughout facilities and time, and that youth in residential care still experience the residential group climate as hard, unsafe and repressive. Notably, Wissink et al. (2019) argued that the cause of violence and repression in residential youth care is not directly influenced by individual characteristics of youth, staff or their mutual relationships. They contend that violence and repression are mainly caused by the residential care system itself, because rights of youth are not always sufficiently guaranteed in the form of legislation, adequate supervision or concrete measures to protect youth in a context that is characterised by extreme power differences between children and staff, lack of evidence-based treatment and discontinuities in residential caregiving (Souverein et al., 2013), violating the first necessary condition for education and treatment, that is, stability and continuity of care (Schulze, 2000).

Therefore, De Lange et al. (2015) issued an urgent call to improve residential youth care on a variety of topics, such as residential group climate, safety, collaboration with caretakers and aftercare.

\subsection{Implications for Practice and Policy}

The Dutch Youth Act gives secure facilities the freedom to make their own policy, which may have advantages, but it seems that policies are not explicit enough about children's rights and violations against (inter)national law. Staff members do not have enough knowledge about international conventions and national law and as a result they sometimes do not know how to deal with situations. This was also a fundamental criticism in the Evaluation of the Youth Act (ZonMw, 2018). Results of the study might be used to make workable instructions for staff members.

The interviews with the children show that they perceive negativity in the secure residential facility. It demonstrates how important high quality treatment is for the child. Compliance with children's rights can be achieved if the facility in question provides a safe and rehabilitative climate at the care unit. It is important to measure group climate on a regular basis, because research shows that achieving a positive group climate can create more attention for the individual needs of the children and more motivation for treatment (Soeverein et al., 2013). A fair attitude towards the child is assumed to result in a greater involvement of children in every process concerning them (shared decision-making, Elwyn et al., 2012). It is imperative that children's voices be heard, and that they be empowered to influence decisions relating to their treatment. And we concur with the recommendations of the United Nations on the Study on Children Deprived of their Liberty (2019). It stated that States 
should ensure that children have access to essential services aimed at their rehabilitation and reintegration into society, including education (Blokhin $v$ Russia), vocational training, family contacts, sports and recreation, adequate nutrition, housing and health care. Health services in detention shall be of a standard equivalent to that available in the community at large (United Nations, 2019: 21).

Children in secure residential youth care do not appear to be making much use of the compliance procedure. Children must be better informed about the complaints procedure, which must be accessible and they must have the right to lodge complaints to an independent and impartial authority on any grievances and human rights violations during detention (United Nations, 2019).

\section{References}

Anckarsäter, H., Nilsson, T., Ståhlberg, O., Gustafson, M., Saury, J.-M., Råstam, M. and Gillberg, C., "Prevalences and configurations of mental disorders among institutionalized adolescents", Developmental Neurorehabilitation 2007 (10(1)), 5765. DOI: $10.1080 / 13638490600864157$.

Barkhuysen, T., "Het EVRM als integraal onderdeel van het Nederlands materiele bestuursrecht" (The ECHR as an integral part of Dutch administrative law), in T. Barkhuyzen, A.B. Blomberg, M.K. Bulterman and J.M. Verschuuren (eds.), De betekenis van het EVRM voor het materiele bestuursrecht. Preadviezen voor de algemene vergadering van de VAR Vereniging voor Bestuursrecht (Den Haag: Boom Juridische Uitgevers, 2004).

Boendermaker, L. and Bruinsma, W., Aanbieders van gesloten jeugdzorg: een overzicht van de stand van zaken (Secure residential facilities: review of the current position) (Utrecht, Nederlands Jeugdinstituut, 2007).

Bray, J. H. and Maxwell, S. E., Multivariate analysis of variance (Newbury Park, CA: Sage Publications, 1985).

Centraal Bureau Statistiek (Central Office Statistics), 2021. DoI: https://www.cbs.nl/ nl-nl/cijfers/detail/84134NED. Accessed 28 July 2021.

Cohen, J., Statistical Power Analysis for the Behavioral Sciences (2nd ed.) (Hillsdale, NJ: Lawrence Erlbaum Associates, Publishers, 1988).

Cohen, J., "A Power Primer", Psychological Bulletin 1992 (112), 155-159. Dor: 10.1037/ oo33-2909.112.1.155.

Colins, O., Vermeiren, R., Vreugdenhil, C., Van den Brink, W., Doreleijers, T. and Broekaert, E., "Psychiatric disorders in detained male adolescents: A systematic literature review", The Canadian Journal of Psychiatry 2010 (55(4)), 255-263. 
Commissie Geweld in de Jeugdzorg (Committee Violence in Youth Care), 2019. Dor: https://www.commissiegeweldjeugdzorg.nl/eindrapport/.

De Lange, M.D., Addink, A.M., Haspels, M. and Geurts, E., Richtlijn Residentiële jeugdhulp voor jeugdhulp en jeugdbescherming (Directive of residential youth care) (Utrecht, the Netherlands: Beroepsvereniging van Professionals in Sociaal Werk/ Nederlands Instituut van Psychologen/Nederlandse vereniging van pedagogen en onderwijskundigen, 2015).

De Valk, S., Kuiper, C., Van der Helm, G.H.P., Maas, A.J.J.A. and Stams, G.J.J.M., "Repression in residential youth care: A scoping review", Adolescent Research Review 2016 (1), 195-216. Dor: https://doi.org/10.1177/0743558417719188.

De Valk, S., Kuiper, C., Van der Helm, G.H.P., Maas, A.J.J.A. and Stams, G.J.J.M., "Repression in residential youth care: A qualitative study examining the experiences of adolescents in open, secure and forensic institutions", Journal of Adolescent Research 2019 (34 (6)), 757-782.

De Valk, S., Van der Helm, G.H.P., Beld, M., Schaftenaar, P., Kuiper, C. and Stams, G.J.J.M., "Does punishment in secure residential youth care work? An overview of the evidence", Journal of Children's Services 2015 (10(1)), 3-16. DOI: https://doi. org/10.1108/JCS-11-2014-0048.

De Valk, S.M., Under Pressure: Repression in Residential Youth Care, Doctoral dissertation (Free University of Amsterdam, 2019a).

DJI in getal [DJI in numbers] 2013-2017, 2019, p. 9o. Retrieved September 2019 from: https://www.rijksoverheid.nl/documenten/rapporten/2018/o8/31/dji-in-getal2013-2017.

Doek, J.E., De herziening jeugdbescherming: IVRK-proof? (The revisions of child protection: UNCRC proof?), in M.R. Bruning and J. Kok (eds.), Herziening kinderbeschermingsmaatregelen. Commentaren op het voorontwerp van de wet (FJRcongresbundel, Deventer: Kluwer, 2008).

Dresen, C., van Domburg, L., Harder, A., Knorth, E., Kranenburg, M., Nijhof, K. and Vermaes, I., "Jeugdzorg met een plus: Wat we wel en nog niet weten over de meest intensieve vorm van jeugdhulp" (Secure residential youth care: what we know and do not know about the most intensive form of youth care) (Antwerpen / Apeldoorn: Garant Publishers, 2017).

Elwyn, G., Frosch, D., Thomson, R., Joseph-Williams, N., Lloyd, A., Kinnersley, P., Cording, E., Tomson, D., Dodd, C., Rollnick, S., Edwards, A. and Barry, M., "Shared decision making: A model for clinical practice", Journal of General Internal Medicine 2012 (27), 1361-1367. DoI:10.1007/s116o6-012-2077-6.

Fazel, S., Doll, H. and Långström, N., "Mental disorders among adolescents in juvenile detention and correctional facilities: A systematic review and metaregression analysis of 25 surveys", Journal of the American Academy of Child and Adolescent Psychiatry 2008 (47(9)), 1010-1019. DoI: 10.1097/CHI.ObO13e31817eecf3. 
Field, A. P., \& Iles, J., An adventure in statistics: The reality enigma ( Sage Publications Ltd, 2016)

Goffman, E., Frame analysis: An essay on the organization of experience (Cambridge, MA: Harvard University Press, 1974).

Hair, J., Black, W., Babin, B. and Anderson, R., Multivariate Data Analysis (7th edn.) (Upper Saddle River, NJ: Prentice-Hall, Inc., 2010).

Heaton, J., "Secondary analysis of qualitative data: An overview", Historical Social Research 2008 (33(3)), 33-45. DOI: www.jstor.org/stable/20762299.

Heynen, E., Roest, J., Willemars, G. and van Hooren, S., "The therapeutic alliance as a factor of change in arts therapies and psychomotor therapy among adults with mental health problems", The Arts in Psychotherapy 2017 (55), 111-115. DOI: https:// DOI.org/10.1016/j.aip.2017.05.006.

Jeugdzorg Nederland plaatsingsgegevens JeugdzorgPlus (Jeugdzorg Nederland placement details secure residential youth care), 2020. Accessed July 2021 from: https://www.jeugdzorgnederland.nl/wp-content/uploads/2021/o4/Jeugdzorg Plus-202O-2.pdf.

Kamerstukken (Parliamentary papers) II 2012 /13 33 684, nr. 3, p.54. Accessed July 2021 from: https://zoek.officielebekendmakingen.nl/kst-33684-3.html.

Kamerstukken (Parliamentary papers) II 1992/93, 22855 (R1451), no.3. Accessed July 2021 from: https://zoek.officielebekendmakingen.nl/ooooo1589o.

Liefaard, T., Deprivation of Liberty of Children in Light of International Human Rights Law and Standards diss. (Amsterdam VU: Antwerp/Oxford/Portland: Intersentia, 2008).

Leloux-Opmeer, H., Kuiper, C., Swaab, H. and Scholte, E., "Characteristics of Children in Foster Care, Family-Style Group Care, and Residential Care: A Scoping Review", Journal of Child and Family Studies 2016, 25: 2357. DOI: https://doi.org/10.1007/ s10826-016-0418-5.

Mijnarends, I., "Het internationale kader" (The international framework), in I. Weijers and F. Imkamp (eds.),Jeugdstrafrecht in internationaal perspectief (Den Haag, Boom juridische uitgevers, 2011, p. 73-105). DOI: http: / /repository.ubn.ru.nl / handle /2066 /74002.

Moerman, G., Probing behaviour in open interviews (Amsterdam, The Netherlands: vU University, 2010).

Olujic, F. and Forder, C., “Gesloten jeugdzorg in het licht van de mensenrechten en de rechten van het kind" (Secure residential youth care in the light of the provisions of human rights and the rights of the child), in C. Forder, W. Duijst and A. Wolthuis (eds.), Kindvriendelijke opsluiting, gesloten plaatsing in het licht van mensenrechten (Leiden, NJCM-stichting Boekerij nr. 53, 2012).

Rubin, H.J. and Rubin, I.S., Qualitative interviewing: The art of hearing data (3rd edn.) (Los Angeles, CA: SAGE, 2012). 
Ruitenberg, G.C.A.M., Het internationaal Kinderrechtenverdrag in de Nederlandse Rechtspraak (The UNCRC in the Dutch rule of law). VU-ACK-reeks (Amsterdam: Uitgeverij SWP, 2003).

Ruitenberg, G.C.A.M., "De uitdaging van het kinderrechtenverdrag voor de Nederlandse rechtspraak" (The challenge of the UNCRC for the Dutch rule of law), FJR 2004 (9), $30-35$.

Schulze, H.J., Stability \& complexity: perspectives for a child-oriented family policy (VU University Press, 2000).

Sonderman, J., van der Helm, G.H.P, Gutterswijk, R. and Stams, G.J.J.M., "Leefklimaat voor meisjes in de gesloten jeugdzorg en justitiële jeugdinrichtingen" (Living group climate for girls in secure residential youth care and juvenile justice institution), in R. Engels and Nijhof (eds.), Meisjes in de zorg, Signalering, preventie en behandeling (Amsterdam: Boom uitgevers, 2015), 131-138.

Souverein, F., van der Helm, G.H.P. and Stams, G.J.J.M., “'Nothing works' in secure residential and correctional youth care?", Journal of Children's Services Review 2013 (35), 1941-1945. DOI: 10.1016j.childyouth.2013.09.010.

Spronk, S.I., "Children's Right to Health in the Child Rights Convention", 2011. DOI: http://dx.DOI.org/10.2139/ssrn.1759897.

Stams, G.J.J.M. and van der Helm, G.H.P, "What works in residential programs for aggressive and violent youth? Treating youth at risk for aggressive and violent behavior in (secure) residential care", in P. Sturmey (ed.) and N.J. Hoboken, The Wiley Handbook of Violence and Aggression 2017. DOI: https://DOI. org/10.1002/9781119057574.whbva116.

United Nations, 1989, Convention on the Rights of the Child. Accessed July 2021 from: http://www.ohchr.org/EN/ProfessionalInterest/Pages/CRC.aspx.

United Nations, 1950, European Convention on Human Rights. Accessed July 2021 from: https://www.echr.coe.int/documents/convention_eng.pdf.

United Nations, 199o, Rules for the Protection of Juveniles Deprived of their Liberty ("The Havana Rules"). Accessed July 2021 from: https://www.unodc.org/pdf/criminal_ justice/United_Nations_Rules_for_the_Protection_of_Juveniles_Deprived_of_ their_Liberty.pdf.

United Nations Study on Children deprived of their liberty, 2019. Accessed July 2021 from: https://www.chr.up.ac.za/images/publications/UN_Global_Study/ United\%2oNations\%2oGlobal\%2oStudy\%2oon\%2oChildren\%2oDeprived\%2O of\%2oLiberty\%202019.pdf.

Van Emmerik, M.L., "Toepassing van het Kinderrechtenverdrag in de Nederlandse rechtspraak" (The direct effect of the UNCRC in the Dutch rule of law), NJCM-Bulletin 2005, 700-716.

Van Gink, K., "Strike while the iron is cold. The adaptation, implementation and effectiveness of non-violent resistance in residential settings for children and adolescents, Doctoral dissertation" (Free University of Amsterdam, 2019). 
Van der Helm, G.H.P., Boekee, I., Stams, G.J.J.M. and van der Laan, P.H., "Fear is a key, keeping the delicate balance between flexibility and control in a Dutch Youth Prison", Journal of Children's Services 2011a, 6: 248-263. D OI: 10.1108 /1746666111119o947.

Van der Helm, G.H.P., Stams, G.J.J.M. and van der Laan, P.H., "Measuring Group Climate in a Forensic setting”, The Prison Journal 2011b, 158-177. DOI: 10.1177 /oO32885511403595.

Van der Helm, G.H.P., Kuiper, C.H.Z. and Stams, G.J.J.M., “Group climate and treatment motivation in secure residential and forensic youth care from the perspective of self-determination theory", Children and Youth Services Review 2018 (93), 339-344. DOI: https://DOI.org/10.1016/j.childyouth.2018.07.028.

Van der Helm, G.H.P. and Stams, G.J.J.M., "Conflict and Coping by Clients and Group Workers in Secure Residential Facilities", in K. Oei and M. Groenhuizen (eds.), Progression in Forensic Psychiatry: about Boundaries (Amsterdam: Kluwer, 2012).

Van den Tillaart, J., Eltink, E., Stams, G., Van der Helm, P. and Wissink, I., "Aggressive Incidents in Residential Youth Care", International Journal of Offender Therapy and Comparative Criminology 2018 (62(13)), 3991-4007. DOI: https://doi.org/10.1177/o3o $6624 \mathrm{X} 18758898$.

Whittaker, J. W, del Valle, J. F. and Holmes, L., Therapeutic residential care with children and youth: Developing evidence-based international practice (London and Philadelphia: Jessica Kingsley Publishers, 2014).

Whittaker, J. K., Holmes, L., del Valle, J. F., Ainsworth, F., Andreassen, T., Anglin, J.P., Bellonci, C., Berridge, D., Bravo, A., Canali, C., Courtney, M., Currey, L., Daly, D., Gilligan, R., Grietens, H., Harder, A., Holden, M., James, S., Kendrick, A., Knorth, E., Lausten, M., Lyons, J., Martin, E., McDermid, S., McNamara, P., Palareti, L., Ramsey, S., Sisson, K., Small, R., Thoburn, J., Thompson, R. and Zeira, A., "Therapeutic Residential Care for Children and Youth: A Consensus Statement of the International Work Group on Therapeutic Residential Care", Residential Treatment for Children and Youth 2016 (33(2)), 89-106. DoI: 10.1080 /0886571X.2016.1215755.

Wissink, I.B., Creemers, H.E., Moonen X.M.H. and Stams, G.J.J.M, Hoofdstuk 4 Deelrapport 2 Commissie Geweld in de Jeugdzorg; Sectorstudie Geweld in de residentiële LVB-jeugdsector (Chapter 4, Part 2, Committee Violence in Youth Care; Violence in Residential Care for Youth with mental disabilities) (Free University of Amsterdam, 2019). DOI: https://www.commissiegeweldjeugdzorg.nl/binaries/ WEB_121512_Eindrapport-Geweld-Deel2_tcm18-393484.pdf.

ZonMw, Evaluatie Jeugdwet (Evaluation of the Youth Act) (Den Haag, 2018). DOI: https://www.rijksoverheid.nl/documenten/rapporten/2018/o1/30/rapport-eersteevaluatie-jeugdwet. 